\title{
Learning to manage quality in a multiple reservoir system: Contribution of a companion modelling approach
}

\author{
Raphaèle Ducrot ${ }^{1,2,3 *}$, Lucie Clavel ${ }^{4}$ and Pierre Bommel ${ }^{5,6}$ \\ ${ }^{1}$ CIRAD, UMR G-eau, Fortaleza, Brazil \\ ${ }^{2}$ CIRAD, UMR G-eau, Montpellier, F-34398 France \\ ${ }^{3}$ FUNCEME, Av Rui Barbosa, 1246, Aldeota, CEP 60115-221 Fortaleza-CE, Brazil \\ 4 INRA; UMR AGIR; 31320 CASTANET TOLOSAN, France \\ ${ }^{5}$ CIRAD, Faculdade de Tecnologia, Universidade de Brasília, Brasil \\ ${ }^{6}$ CIRAD, UR Green, Montpellier, F-34398 France
}

\begin{abstract}
The development of water policies based on integrated water management principles promotes the development of multistakeholder platforms to manage water resources at catchment level. This is the case of the Alto-Tietê watershed, the urban catchment encompassing the São Paulo metropolis in Brazil. The dynamic pattern of peri-urban areas characterised by rapid major changes has led to complex management issues in which the quantity and quality dimensions of water are intertwined. Effective participation of a broad spectrum of stakeholders supposes that actors from different technical backgrounds have a better understanding of the social and biophysical interactions of the system concerned. This paper describes the role of participatory modelling and simulation as a way to provide a meaningful framework to enable actors to understand the interdependencies in peri-urban catchment management. A role-playing game, connecting the quantitative and qualitative dynamics of the resources with social interactions at catchment level, was developed and tested with members of the catchment committee. Monitoring of the sessions underlined the role of such a tool in learning about collective water management.
\end{abstract}

Keywords: peri-urban catchment, eutrophication, companion modelling, participatory modelling, water allocation

\section{Introduction}

Integrated water resource management (IWRM) currently features in many legislations, for example in the European Water Framework Directive and in Brazilian water legislation. In spite of its wide and consensual acceptance, IWRM has a number of different weaknesses. It remains a prescriptive and ambiguous concept that relies on different presuppositions, such as the availability of information or previous institutional reforms. Implementation is an extremely challenging process because of the need to account for multiple interests and to integrate complex interactions and dynamics at different levels and scales. This includes the integration of the biophysical and social systems, the quantitative and qualitative aspects of water, land and water at the territorial level of management, as well as the technical, financial and legal aspects of water management (Pahl-Wostl et al., 2005; Wietske et al., 2005).

These interdependencies are particularly complex in periurban areas, which are undergoing urbanisation processes and include both rural and urban features. They are affected both by the increasing competition between urban water demand and rural and agricultural uses in particular. Increasing urban demand often leads to the transformation of the natural hydrological network with the development of new infrastructure

\footnotetext{
* To whom all correspondence should be addressed.

푠 +55 (85) 3101-7022/+55 (85) 9657-2314; fax: +55 (85) 3101-1093; e-mail: raphaele.ducrot@cirad.fr

Received 16 September 2009; accepted in revised form 8 November 2010.
}

(reservoir, canals etc). While these fulfil specific hydrological functions for the city, i.e., a catchment area includes space for drinking water reservoirs and enables groundwater recharge, population growth affects natural hydrological processes through the expansion of impermeable surfaces, and pollution of surface and subterranean aquifers (Dourojeanni and Jouralev, 1999). One of the consequences of urban wastewater discharge in water bodies is eutrophication driven by excessive inputs of phosphorus and nitrogen (Von Sperling, 1997). This process is often linked to illegal occupation of environmentally unsuitable areas and urbanisation in the form of shanty towns that have no access to sanitation (Baroos and Linden, 1990; Brennan, 1994; Douglass, 1992). Water management in these areas requires the development and management of a potable water supply and sanitation services. It also requires basin level management to coordinate multiple water uses and to protect the basin against flooding and pollution. Thus the governance of water services and water resources - traditionally tackled separately - are in fact intertwined and both have to take into account the dynamic pattern of peri-urban areas characterized by rapid and major changes. This leads to complex technical problems (type of infrastructure and maintenance) and economic problems (tariff structure, level, collection), but also to organisational and social issues. Institutions very often have both a sectorial and rural/urban orientation (Mattingly, 1999). Very different kinds of stakeholders (in terms of power, organisation, and access to information) are involved, from domestic users who are not necessarily well organised, to powerful administrations and/or water supply firms. New institutional arrangements have been implemented to strengthen 
participatory decision making in water and land management and to involve the whole spectrum of stakeholders. But effective participation remains limited, partly due to the complexity of the processes and interactions involved and also because differences in access to information make it difficult for people to acquire a broad understanding of the hydro-social functioning of the catchment.

In water management, biophysical modelling and geographic information systems have long been used to account for the complexity of biophysical processes and the land-water interactions in a spatial context. They also enable integration of multi-disciplinary knowledge (Bousquet and Le Page, 2004), and simulations allow managers to safely experiment with management choices (and thus policy options) (Mayer and De Jong, 2004). Many modelling works are supported by the idea that scientific information is the key for decision making, following the prominent hypothesis that there can be rational and objective management of natural resources or that science provides unambiguous answers. But the difficulties encountered by the actors in making efficient use of the scientific information - for different reasons such as an inappropriate modelling scale for decision making (Leopold et al., 2006), or difficulties for non-scientific users to understand and explore the data and models provided (Oxley and Lemon, 2003) - have led scientists to question the place and role of information flows in water management. The increase in the participation of non-experts in water management makes this concern even greater. It presupposes the integration of different types of information: scientific andtechnical but also traditional, cultural and local (Baumgartner et al., 2002; Folke, 2004). How can this be achieved? Sharing information between different actors with many different points of view and skills is an issue (Ozawa and Susskin, 1985). Different paths are currently being explored such as the specification of a multi-perspective set of economic, environmental and social indicators (Ewert et al., 2006), a stronger focus on the communication capacity of the model (quality of its interface, etc.) as part of the quality of the modelling process (Horlitz, 2007) responding to the users' request for information (McNie, 2007). But these possible ways of communicating only partially reduce the gap between scientists and decision makers (Borowski and Hare, 2007). Learning theories emphasise that making sense of information is different from simply possessing information. It requires a process of appropriation of the information based on the mobilisation of experience or calling up of memory, followed by a phase of conceptualisation or comprehension through internal, reflective processes and/or experimentation (Kolb, 1984; PahlWostl, 2002). In a collaborative context, cognitive learning experiences pointed to the role of dialogue and interaction in the conceptualisation processes (Baker, 2004). This underlines the need for methods that are able to facilitate the exchange of information between stakeholders from different cultural backgrounds, as well as for the development and mobilisation of experiences and memories related to this information.

The objective of this paper is to describe the role of a participatory modelling and simulation exercise as a way to design and create a meaningful framework to enable actors to understand the interdependencies in the management of periurban catchments. The paper argues that experiencing a virtual interactive management situation that combines social, legal and biophysical aspects provides a comprehensive framework of the whole complexity of the peri-urban catchment concerned. It helps actors to identify the different dimensions and relevant interaction mechanisms to be taken into account in the decision making process. Such learning can support collective water management which takes the complexity of the system into account instead of trying to simplify it. It also provides a basis for more complex participatory simulation processes.

The methodology used is based on the Companion Modelling approach (ComMod, 2006) a participatory modelling approach using social simulation in various forms to understand and strengthen the collective decision-making process of stakeholders sharing a common resource. In this approach, simulation models integrate the different stakeholders' points of view and are used as platforms for collective learning. Preference is given to models that allow social and decision-making processes to be explicitly represented, especially through multi-agent models and role-playing games (RPG). There has recently been increased interest in the use of such tools in the field of water management. The approach has been tested to support the creation of water institutions in Asia (Gurung et al., 2006) and to strengthen capacity building in watershed management in South Africa (Farolfi and Rowntree, 2005). Both experiments focused on the coordination mechanisms involved in sharing the water viewed as a common pool (flowing) resource, whereas little attention was paid to the technical aspects of management, such as issues of quality or infrastructure. Our work pays closer attention to these aspects.

After presenting the context of the Alto-Tietê Cabeiceras catchment, where this study was undertaken, we describe the methodology used to collectively develop the role-playing game as well as the content of the game model used. In the last section, we discuss the learning processes and the limits of this approach in the context of our study.

\section{The study area: the ATC sub-catchment}

The headwater catchment of Alto-Tietê Cabeiceras (ATC) is one of the 5 sub-catchments of the Alto-Tietê (Upper Tietê) basin, which concentrates $99 \%$ of the population of the Metropolitan Region of São Paulo (MRSP). Though population growth has decreased during the last 15 years, the MRSP integrated water supply system is now reaching its limits. The Sabesp (Compánia de Saneamento Básico do Estado de São Paulo), the public company in charge of the São Paulo water supply, already has to import half of the $60 \mathrm{~m}^{3} / \mathrm{s}$ of water needed to supply the metropolis, from a neighbouring catchment. The ATC sub-catchment already provides $25 \%$ of the RMSP water through 2 hydraulic systems, called production systems - the Rio Claro and the Alto Tietê Production Systems (or SPAT). It remains the best preserved of all the Alto Tietê sub-catchments and thus plays a strategic role.

The catchment covers $1694 \mathrm{~km}^{2}$ upstream from the MRSP and includes 9 municipalities. The 6 downstream municipalities are typically peri-urban. They host 1.8 million inhabitants (1 101 inhabitants per $\mathrm{km}^{2}$ ). These municipalities are supplied by the MRSP integrated water supply system. The 3 municipalities located in the upstream part of the sub-catchment are still very rural and are supplied by an independent water supply system managed by the municipalities or by the Sabesp.

The study focussed on the $919 \mathrm{~km}^{2}$ catchment area of the Alto Tietê production system, which is a good example of the struggle between water quantity and quality for urban supply. This system produces $10 \mathrm{~m}^{3} / \mathrm{s}$ (to be increased to $15 \mathrm{~m}^{3} / \mathrm{s}$ by 2015). Its construction started in 1972 with the Ponte Nova reservoir, originally built for flood protection. Between 1976 and 2006, 4 additional reservoirs were built, filled and connected to the Ponte Nova reservoir to satisfy increasing demand for 


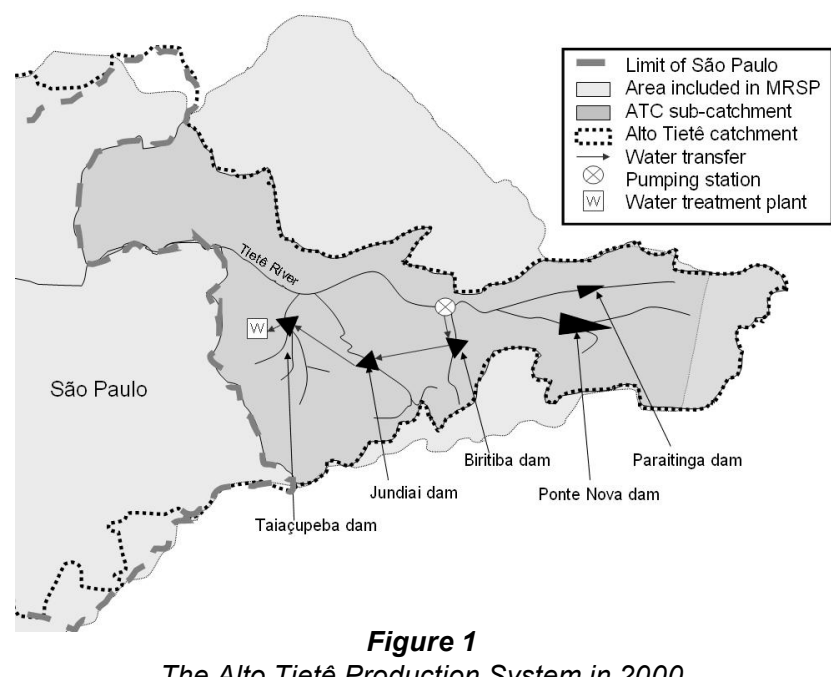

The Alto Tietê Production System in 2000

water for São Paulo. The Alto Tietê production system does not only supply the MRSP demand for water. Its manager (DAEE, Department of Water and Electrical Energy) also has to deal with local demand. Three municipalities have independent water services and together consume $0.47 \mathrm{~m}^{3} / \mathrm{s}$. The demand from local industries is high at $4.96 \mathrm{~m}^{3} / \mathrm{s}$ (Suplicy, 2002). The sub-catchment is also characterised by intensive irrigated agriculture that consumes an average of $2.13 \mathrm{~m}^{3} / \mathrm{s}$ per year $(81 \%$ of MRSP irrigated area is located in the ATC sub-catchment). The Tietê flow is also used to dilute downstream effluents from the metropolis and consequently a minimal flow has to be preserved at the catchment exit.

Like the other peri-urban catchments in the MRSP, the catchment has been under land use restriction since the 1970s in order to control urbanisation and subsequent pollution. Most releases of polluting water thus occur downstream from the dams and are controlled through a system of water release licences. Apart from a small area of irrigated agriculture, extensive cattle raising, and a city of 26000 inhabitants, which treats about $50 \%$ of its effluents (Suplicy, 2002), the production system catchment area only contains forests and eucalyptus plantations.

Since 1997, the eutrophication rate of the Taiaçupeba reservoir, where the Sabesp potable treatment station is located, increased significantly, resulting in an increase in treatment costs. A high eutrophication rate is also observed in the Jundiai reservoir, which is not coherent with:

- The land use located upstream from the reservoirs

- The depuration capacity of the rivers (see organization of the sub-catchments in Fig. 1).

The origin of the pollution has been questioned, especially the role of agricultural land use. In 2005, Sendacz showed that the increasing eutrophication in fact resulted from the management of the hydraulic system itself, through the transfer and accumulation of nutrients by water transfers between dams (Sendacz et al., 2005). An increase in nutrient concentration is common when dams are filled, even more so if the dams are not previously deforested (Bianchini Jr., 1999). To respond rapidly to the increased demand for water, the managers did not wait for the water quality to stabilise in the new reservoirs and nutrients were consequently transferred to the last dam. However, the role of agricultural land-use remains a conflictual issue within the committee.
In the 1990s, the São Paulo State created catchment committees that were supposed to represent all water users of a catchment and thus give the State a better overview of catchment issues and users' stakes. Each sub-catchment of the Alto Tietê also has its own sub-committee gathering together representatives of government institutions, municipalities and organised civil society. The ATC sub-committee is the only one to represent people in the agricultural sector. Only recently implemented, this new discussion forum is already facing difficulties in functioning.

We proposed to use a companion modelling approach to strengthen the capacity of the sub-catchment committee for discussion. The specific objective of our approach was to design a RPG to allow the members of ATC sub-catchment committee to discuss not only coordination issues but also technical ones, particularly the relationship between quantity and quality at the catchment level. By gathering around the same table people who in practice act individually in space and time, we expected to facilitate learning processes concerning the complex interrelationships between society and the biophysical dynamics at catchment level.

\section{The companion modelling approach}

The design of the AguAloca RPG was part of a process called Agualoca (Fig. 4). This process started by field work organised by topic (e.g. land use dynamics, reservoir functioning, stakeholders and conflicts). This field work enabled the collective development of a general framework of the game, which was used to develop a RPG and its underlying model, and to identify information relevant for the players.

\section{The development of the game}

The design phase of the game was seen as a key opportunity to integrate the knowledge of different scientists around a common question. Rather than a simple exercise of developing a didactic tool, the development was explicitly treated as a participatory modelling process. It permitted us to specify the representations of interactions between actors and resources in a given spatial territory. This implied specifying and comparing

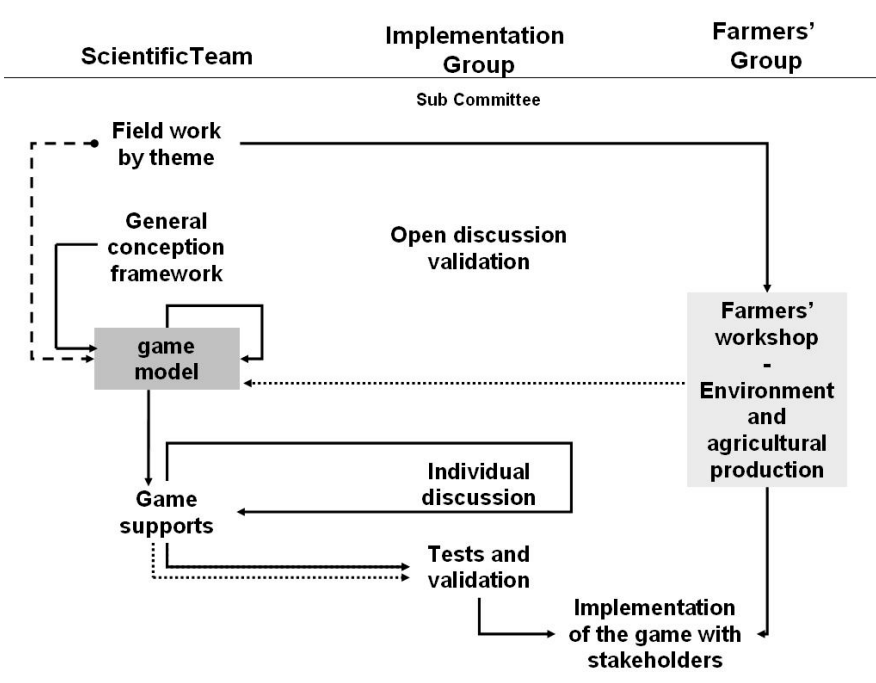

Figure 2

Methodological development, the AguAloca process 
the perceptions and representations of different participants about social and biophysical dynamics. In turn, this required selecting a representation that would make sense to all participants and include all potential players.

A working group composed of modellers, agronomists, sociologists, hydrologists, and economists was responsible for developing a conceptual framework representing interactions between the social and biophysical dynamics, that stakeholders would be able to use as a virtual negotiation platform. To formalise these dynamics and interactions, we followed the 'actors-resources-dynamics-interactions' methodology proposed by the Companion Modelling group (Etienne, 2006).

The proposed framework was discussed twice with a small group of very active members of the catchment committee. These discussions enabled us to check the relevance of the framework proposed for the actors' representations. Farmers' perceptions were only indirectly integrated through input from an agronomist, who undertook specific activities with farmers concerning the organisation and development of less polluting activities, since we thought it would be difficult to directly mobilise farmers' representatives as they felt threatened by the discussions taking place in the committee, whose members regularly blamed agriculture for the level of pollution.

This consensual model was then used for the elaboration of the game material (gameboard, description of the players, information content, and computer model). The game was then tested and validated with students and with the focus group of the sub-committee.

\section{The AguAloca RPG}

The AguAloca game is a computer-based role-playing game developed using Cormas, a multi-agent computer program. Its aim is to simulate negotiations related to water allocation and its impact on water resource quality at catchment level.

We decided to design a fictitious catchment representative of the Alto Tietê Cabeceiras sub-catchment in terms of environment (elements of the landscape), society (actors), the institutional and legal context (catchment committee, water licences, water quality classes). The purpose of this decision was to create an environment far enough from reality to avoid reproducing specific or personal conflicts but close enough to allow the players to easily identify with their roles and decision making. The game environment was thus a peri-urban

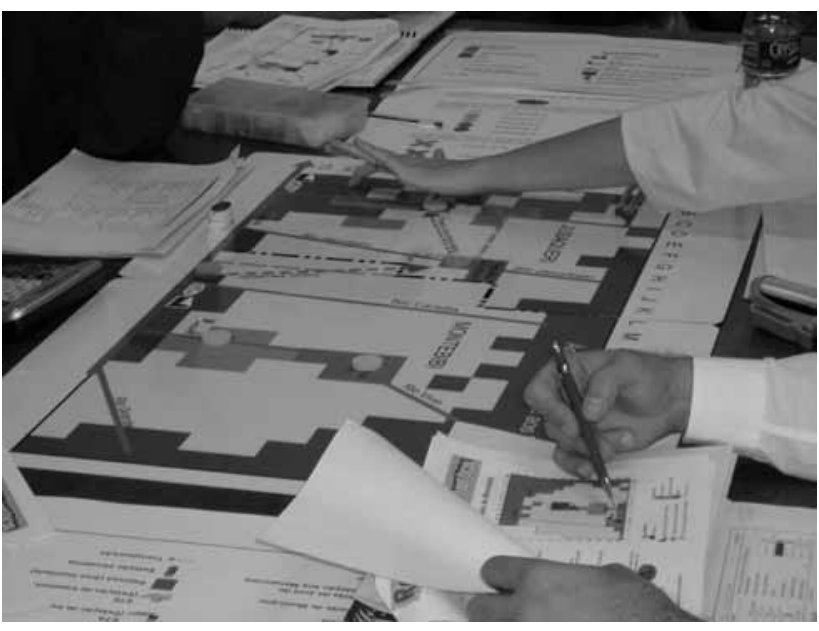

Figure 3

The AguAloca game board catchment located upstream from a large urban area, which supplies the water to the urban area.

The virtual peri-urban catchment is characterised by differences and competition between water uses. Two municipalities are represented. The first, located close to the city, is typically peri-urban and is connected to an integrated water supply network supplying a metropolitan area located downstream from the virtual territory. The second municipality, located upstream, is typically rural and has an independent water supply and sanitation system. The agricultural sector is extensive and is characterised by different levels of irrigation for horticultural crops. Agriculture is grouped in 3 different areas and is assumed to be practised by a large number of small-scale farmers. The industrial sector includes 2 paper factories in the catchment. A complex hydraulic system was built to supply water to the city downstream and to local water users. It is composed of 3 dams interconnected by 2 channels. This context is depicted on a colourful stylised game-board that represents 4 different land uses (urban, agriculture, forest and other) in defined areas (each one representing $5 \mathrm{~km}^{2}$ ), with the different water bodies (e.g. rivers, canals and dams) depicted as blue lines and triangles.

Only 5 types of actors are represented in the game, which requires 6 players. We purposely selected only stakeholders' roles that:

- Had a direct impact on the water flows in terms of quantity and quality

- Were represented within the catchment committee.

The mayors of the 2 municipalities have to ensure access to water services (e.g. water supply and sanitation) by their inhabitants. The water company has to operate the integrated water and sanitation system of the downstream city and the neighbouring peri-urban area, to which one of the 2 local municipalities belongs (the downstream one). The farmer's representative has to defend agricultural interests and give advice regarding the choice of crops and irrigation practices to farmers who are not physically present. The industrial representative runs the 2 paper factories. The Catchment Water Department operates the hydraulic system respecting the users' water rights: its aim is to transfer water between dams in order to satisfy all users' demands.

Decisions made by players have an impact on water demand depending on production decisions and/or the release of effluents. For example, the player who manages the water treatment plant can modify the water treatment capacity, water treatment objective, treatment process and supply network, while the player who manages the sewage plant can modify its water treatment capacity, water treatment objective, treatment process, and sewage collection network.

In practice, the 6 players sit around the game board and make their personal decisions based on players' information sheets which describe their own situation (e.g. the paper manufacturer knows the production capacity of each paper factory and can modify it). The game is divided into 6-month rounds which correspond to the rainy and dry season. This time step is representative of stakeholders' strategies, particularly those of farmers and of the water department. Each round starts by an individual phase when each player has to make personal decisions regarding the system for which he is responsible and its own objectives (e.g. the water department can adjust the flow downstream from each dam). This individual phase is followed by a collective phase simulating a catchment committee meeting, where all players can discuss their past actions and elaborate collective strategies. 


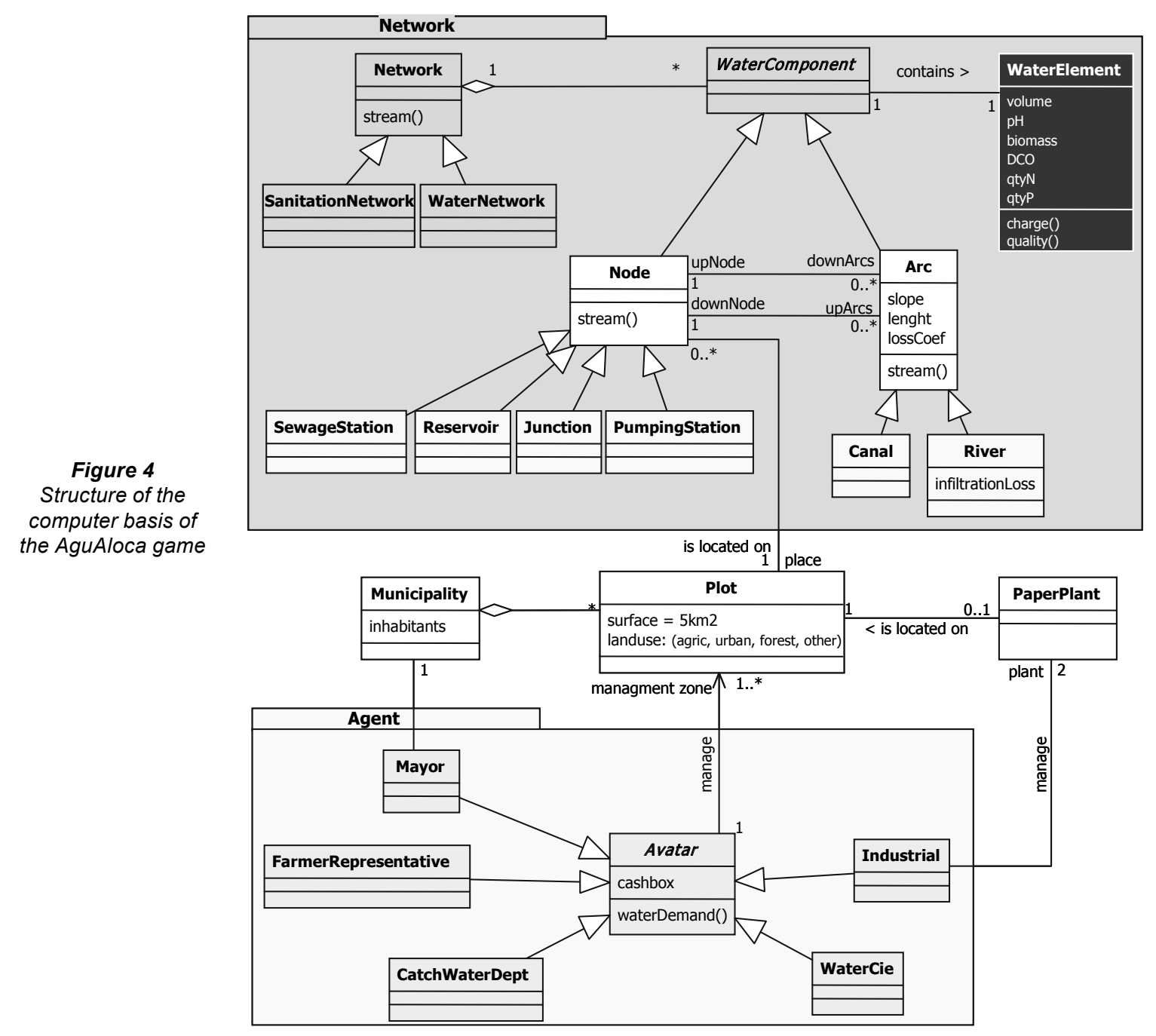

During the collective step, the model quickly processes personal decisions in a biophysical model which then simulates the impacts of personal decisions on the environment, and updates the players' information sheets.

\section{The underlying biophysical model}

The game aims to simulate negotiations concerning the quantity and quality of water resources at catchment scale, by focussing on eutrophication processes for the quality part. Other pollution processes in the area are not well documented as eutrophication currently appears to be the most frequently discussed pollution issue in the catchment, and is the subject of different conflicts. Relationships between water quantity and quality are the result of:

- Management of the water system at local scale or at a higher level (management of dams and transfer of water)

- Actions of different local users (e.g. uptakes and releases from cities, irrigated agriculture and industry)

- Changes in local land use which have an impact on water balance and diffuse pollution.

The use of a computer-based model appeared to be the most efficient way of integrating processes that occur at different spatial, social or temporal scales, and involve complex calculations. The underlying biophysical model was developed by simplifying and combining existing hydrological models in the area. It contains 3 modules.

Inspired by the MQUAL (Prime Engenharia, 1998) model, which is the first existing representation of quality processes in the area, we developed a nutrient export module to estimate phosphorus exports resulting from local land uses. For this purpose, the catchment was divided into 299 cells of $5 \mathrm{~km}^{2}$ each. Each cell is characterised by a single land cover (e.g. forest), which is associated with a phosphorus export coefficient defined by MQUAL for a neighbouring sub-catchment (the Guarapiranga sub-catchment). Cells can be aggregated into micro-catchments enabling estimation of phosphorus exportation at meso-level.

We used the formalism of an existing model (ACQUANET) to simulate water allocation in the Alto Tietê production system. We developed an arc-node model to allow transfers of water and phosphorus between different places in the hydrographical network. Arcs represent superficial and channelled flows (i.e. rivers and channels). When the flow of water transferred by one arc remains constant (not including infiltration or the contribution of the aquifer), the phosphorus charge transferred by an arc decreases, following an exponential decrease equation (Porto, 2003). Nodes represent specific points in the hydrographical network where a change in water flow and phosphorus concentration may occur (i.e. water uptake and release, dam). The different kinds of nodes reflect the way 
they modify flows and phosphorus concentrations. The catchment node is associated with a virtual micro-catchment which gathers data on rainfall and on nutrient charges to be introduced in the arc-node system. The junction node represents the tributaries and can add flows and concentrations from different tributaries. The demand node is used to remove water from the arc-node network. The dam node is used to simulate the specific processes that occur in the reservoir, such as nutrient concentrations (Fig. 3). These processes are simulated by the use of the Vollenweider equation (Jørgensen, 2000). As each action of the players concerns a specific node, this architecture enables representation of the impacts of local actions as well as that of the water management system.

The model also enables representation of the main trends in land use change, e.g. population pressure. The last module simulates the migration of families within a given area. Mayors can influence where migrants settle by selecting specific areas. The model will then allocate half the families to these specific cells and the rest to other cells to simulate unorganised urbanisation.

\section{Information management}

While the RPG allows players to interact on land and water management issues, the simulation model enables estimation of indicators that players can mobilise for their actions. The indicators are provided individually as a data sheet table that is freshly printed at each time step. The management of information between the model and the players in the form of indicators facilitates both the players' individual actions and interactions among players. An indicator can be mobilised during a discussion as an argument, an example or an objective.

The model outputs are displayed to players according to specific rules designed to mimic realistic and differential access to information. For example, water quality is checked at different places in the hydrographic network and the data are only available to the water company: the quality indicators simulated by the model only appear on sheets distributed to players who have to deal with the water treatment plant (i.e. the water company and the mayor of the upstream municipality).

The game enables players to share information if they decide to do so. The players can exchange information orally during the simulation of the catchment committee meeting. To facilitate the exchange of information, colourful chips are provided that can be used on the game-board. The shape of a chip depends on the nature of the information (e.g. information on water quantity is represented by a cross), and the colour of the chip indicates the type of information (e.g. a round blue chip represents good water quality whereas a red one represents bad water quality). The way the information is shared during the game can thus be analysed during the debriefing session after the game.

\section{Monitoring and assessment}

Two game sessions were monitored and evaluated. The first game involved Sabesp engineers and representatives of local municipalities. The expectations of this group were rather confused and their concerns were mainly technical. The second game involved members of the Alto-Tietê catchment committee. All players had a university education but some were less familiar with technical issues than others.

Each game session lasted between 4 and 5 hours enabling from 3 to 4 rounds (2-3 hours) and full debriefing (1-2 hours) to take place. The game sessions were monitored by:

- Two people who observed the development of the game by focussing on the individual and collective behaviour of the players (using observation guidelines)

- Two questionnaires, one of which was given to the players before the session started to assess their expectations about the session, and one which was given at the end of the sessions to assess their satisfaction and possible learning

- A camera that recorded all the game sessions for further analysis

Analysis of the learning processes used a theoretical framework based on both cognitive and social learning. Different types of learning were differentiated:

- Individual learning concerning the acquisition of new skills, competencies, or technical knowledge as well as relational learning

- Learning concerning the issue as a whole in its integrated dimension, stakes and parties involved

- Situational learning concerning the development of networking, collective memory, rules for social interaction, and knowledge sharing.

\section{Discussion}

\section{Is a virtual catchment a valid representation of a complex reality?}

\section{A semi-validated biophysical model}

The underlying biophysical model was built for the specific purpose of the role-playing game. This presupposed making some simplifications regarding the biophysical processes to enhance the 'gameplay' (this term refers to sets of rules in a game that are intended to produce a stimulating gaming experience), while demonstrating the main trends observed within the ATC sub-catchment (e.g. phosphorus transfer between dams, phosphorus loads from urban areas). As phosphorus is considered as a limiting factor of eutrophication in tropical areas (Salas and Martino, 1991, in Von Sperling, 1996), it was the only nutrient taken into consideration.

A monthly time step was selected to match the actors' time scale and gaming objectives. However, this choice can be questioned as far as the eutrophication processes are concerned. Nutrient (and thus phosphorus) discharges within water bodies are closely linked with precipitation intensity (Shigaki et al., 2007) which can be measured daily or at a shorter time step. We assumed that the monthly time-step blurs the effect of precipitation intensity over nutrient discharge rates. Nevertheless, both the Vollenweider equation and exponential decrease integrate the average retention time, which characterises the average time needed for one substance to leave the water body concerned (Straskraba, 1999). This means the players have a reasonable overview of changes in the eutrophication rates from one season to the next.

The simplification also applies to the land use classification and thus the related phosphorus export coefficients. These coefficients have only 3 basic values: forest, agricultural land and urban zones (the urban phosphorus export has a base value and is recalculated as a function of the population and access to the sewage network). As the number of values for the phosphorus coefficient is limited, it is easier to understand that land use has an impact on eutrophication dynamics.

While the different quality modules (land use phosphorus exportation module, the exponential decrease in the river and 
the Vollenweider equation) had previously been validated in specific local situations, their connection in a single model at catchment level had not yet been implemented and validated at catchment level. Only the flows of the adapted hydrological model that had previously been validated and calibrated at catchment level were provided to players by means of quantitative indicators, as the dimensions of the virtual catchment and hydraulic elements were comparable to real situations. But the phosphorus level was provided in the form of a quality state of the water bodies instead of the exact eutrophication rate. This choice also blurs changes in the eutrophication rate but has the advantage of being understandable: for un-initiated players as only 5 eutrophication classes are used; and for the water eutrophication specialist - the eutrophication classes represented were proposed by a Brazilian limnologist (Von Sperling, 1996). Moreover, the classification directly refers to the water quality legislation which also uses 5 water quality classes even if these classes were built using a complex indicator that aggregated different markers.

\section{The structure of the game and interaction with the biophysical model}

While the use of a biophysical model was based on some research works (particularly the interaction between water quantity and quality management), the game-board and the organisation of the game were based on the actors' perceptions. The game structure is directly related to the conceptual model built collectively using the ARDI (Actors, Resources, Dynamics and Interactions) approach. This method focuses on the direct interaction between actors and the resources, and thus on the actors and practices that directly affect water flows in quantity and quality, and vice versa. For example, a mayor has to deal with the development of water infrastructure and migrants' spatial allocation, but is not involved in infrastructure for education or health. The players only receive limited options for action and their choices only mobilise a couple of indicators, whereas in real life their choice could be far more complex. For example, there is only a choice of 3 different treatment schemes (A, B, C), which differ in their cost and efficiency. Thus the possible solutions to problems identified during the game are constrained by the game structure. But the indicators we selected were the direct result of thematic field work, including interviews with actors, and had been validated by the actors involved in the creation of the game. Thus, although simplified, the decision-making process made sense to the players. However, at the individual level, the solution an actor chose is less important than the process by which he made his choice, as a result of interaction with the materials and other players.

The calibration and support material was organised so that the players do not have to calculate anything, but technical knowledge is required of how to read charts and abaque. For example, managing a hydraulic system comprising 3 reservoirs is a technical task. In practice, only the 30 years of experience and an in-depth knowledge of the system enable the manager of the water department to adapt his daily management to rainfall and to changes in SPAT. The water company in charge of the basin that does not have the same experience developed a simulation tool based on optimisation to be able to manage the system according to its own interests. To facilitate the management of the virtual system by non-specialists, the game includes a predefined management strategy for the 2 seasons (by defining a medium flow release for each reservoir and canal). However; the parameters can be changed to suit the situation or the demands of other actors during the game. These strategies were built following the rules of the real-life manager of the system. But the arc-node representation was inspired by the optimisation tool used by the water firm, so both the water firm and the water manager felt at ease with the representation, as was revealed by the monitoring of the game. Nevertheless, this role is highly technical and an actor with no hydrological background would find it difficult to play. Because of the information that was provided, some players tended to only focus on numbers, which limited their interactions with other players.

The aim of the game is not to represent reality but rather to caricature reality in order to reveal the interactions and related problems, and the different aspects taken into account by stakeholders during the course of individual and collective decision making. It was intentionally designed to reflect the complexity of real situations and thus to include different types of conflicts at the same time with no obvious collective solution. The model was calibrated so as to provide plausible data and discussion issues at catchment level. It consists of a learning round, followed by a pollution crisis in the second or third round. This was made possible by choosing a rainfall sequence that rapidly resulted in water scarcity, which helped increase pollution due to different actors' practices. As conflicting management situations result from the combination of practices, to understand the origin of the situation players have to have in-depth discussions and share information among themselves. As the problems cropped up at different points in the basin and, as in real life, all the problems were interconnected, it was impossible to solve the crisis by simply implementing a technical action. Going beyond technical proposals was one of the purposes of our experiments.

\section{A limited social model}

If the biophysical model and the virtual situation reflected the situation in the catchment (although in a simplified way), the social aspects represented by the roles of the players and their specifications involved a number of limits.

The players' roles do not represent all the groups of stakeholders involved in catchment management, or the exact representation of the catchment committee. This is due to the elaboration mode of the underlying model of the game and the need to avoid players remaining inactive in the game. This strategy ends up favouring actors who have a direct influence on the water resources. Other indirect actors like regulators were not included in the game even though during the elaboration phase they had been identified as important stakeholders. Other actors were excluded by the choice of scale of the approach, which was defined by the objective of the work and which represented a compromise between representation constraints and territorial levels expressed by participants. In particular, this excluded actors who intervene at a more local level and are not involved in collective actions at catchment level, notably farmers, local residents or community leaders. As in real life, a farmers' representative was designated in the game, but this player has (in the game as well as in real life) very little control over the activities of the farmers who influence the water resource either by irrigation or pollution. This is related to the type of irrigated agriculture in the area, which was developed by small-scale horticultural farmers (average farm size $5 \mathrm{ha}$ ), with individual pumping from water streams or small private water tanks, and with very little tradition of collective action except for incipient local initiatives related to the sale of farm products. It nevertheless occurred that part of the discussion during the game focussed on agriculture issues, either as an 
activity affected by water management at catchment level or as a potentially polluting activity. The discussions underlined the fact that most participants were not well informed about agricultural activities. The interests of local residents or community leaders focussed on land title regularisation and household access to urban infrastructure, subjects that are difficult to tackle efficiently at catchment level. It would have been possible to represent all the levels from plot to catchment scale using spatial aggregation. But this would have led to a very complex game with a high risk of reducing its explanatory and structuring strength, which is one of the main contributions of the game to collective learning.

The game structure and discussion allows 2 types of interactions between players (bilateral negotiations and collective discussion as a way to represent a catchment committee meeting). Bilateral discussions are more focused on specific negotiations, while collective discussions generally take the form of a collective diagnosis of the situation. But the time allowed for the discussion is too short to lead to complex negotiation that would require different timing and alliance building. At the most, the allotted time allows identification of the difficulties involved in negotiation.

The explicit definition of the roles, and the information focus on the interests of actors, as users of the resource (with direct economic interests, or indirect ones in the case of the advisory role of the agricultural representative,) or managers, does not prevent players from including other concerns in the discussion, depending on their own interest or perception. Environmental or social arguments generally emerged during the discussions. However it is true that the complexity of social relationships, which includes power relationships, and different kinds of social ties embedded in an historical context, is not included in the game. In addition, players bring to the game their own complex politico-social context even if the gaming atmosphere enables this to be partially overcome. Using a virtual situation to simulate both environmental and social contexts avoids bringing up old consolidated conflicts which would inhibit fruitful discussion. It allows participants to explore solutions that would be difficult to tackle in a normal situation and to overcome situations that in real life are locked in. Maintaining a good game atmosphere is a precondition for tension-free and enjoyable discussions which enable players to partially and momentarily put aside their social roles.

Even though is it important to consider the coherence of the modules when assessing the adequacy of the model, the validation of a semi-open system such as ComMod RPGs remains an epistemological issue. Following the discussion concerning the validation of multi-agent systems, this is probably more related to its ability to represent the capacity of adaptation, emergence and/or resilience of the open socio-ecological system that it aims at representing than to adherence to existing data (Bommel, 2009). As such, the emergence during the game of conflicts which mimic existing tensions at catchment level is particularly interesting.

\section{Learning about catchment management by investigating interactions in a simplified representation}

Collective discussion during the 2 games focussed on the management of water quality (Jacobi and Granja, 2006) but their real contents were influenced by the profile of the group. In the first group, collective discussion was dominated by technical arguments. Not surprisingly, the second group appeared to be more collectively aware of the political aspects of water management, its complexity, and the importance of negotiation, and were less concerned with technical problems (Jacobi and Granja, 2006).

Assessing the learning processes emphasised the role of the game as a meaningful model of catchment functioning. Many participants stressed the quality of the game supports (board, model of a virtual catchment) that were supplied as a support for meaningful discussions about catchment issues. In particular, the game contributed to a new concrete understanding of the notions of 'integrated or shared water management' or 'collective action related to water management'. It highlighted the underlying interactions between different activities at catchment level and enabled the players to better understand the interests of the other stakeholders. The RPG helped players to organise and structure diverse technical and social knowledge and information and thus to give a coherent meaning to complex real situations. It also contributed to a better understanding of the management stakes at catchment scale. But the learning process is not limited to organising and structuring knowledge, information and individual perspectives. Experimenting with the model allows issues to be appropriated and questioned by participants. For example, participants who initially had strong stakes in water management but who expressed them only in terms of quantity and allocation issues, started to question the relationships between quantity and quality at catchment level. As a result, specialists were invited to present their findings in more detail and a discussion workshop on the quality issues was organised by the committee some months later.

Three mechanisms contributed to these learning processes:

- The investigation of the biophysical model

- The experimentation of other roles

- The argumentation and explanation linked to the management of information

\section{Investigation of the biophysical model}

Monitoring of the game underlined the fact that once they became familiar with the available information, some players started to investigate the underlying model, particularly by testing its quality aspects. For example, in the quality module of the model, one player who knew about water allocation models investigated the possibility of diluting water effluents. A manufacturer decided not to treat effluents from the paper factories to assess the impact of this decision on water quality downstream, and a participant who played the role of farmers' representative tried to promote rural sanitation to assess its potential impact on water quality.

Some players investigated the relationships between water management and urban planning but they were frustrated by the highly simplified representation of land use and population dynamics. This was also due to a rather perfunctory vision of land planning and urbanisation control: once an agreed zoning policy was in place, municipal players expected the (simulated) families to act exactly according to their plan, but the software did not necessarily take into account what the urban planners had selected - as real life behaviour does not follow planning prescription.

But the duration of a game session (which at most includes 4 or 5 rounds) limits the exploration of scenarios. This prevents correct assessment of the possible outcomes of one decision. This is why such games can be useful when they are coupled with simulation exercises based on calibrated models. The RPG raises the participants' awareness of the interest of simulation and scenarios whose potential contribution is not always as well perceived by stakeholders as assumed by scientists (Becu 
et al., 2008). While the game can help participants who are unfamiliar with modelling to understand the meaning, contribution and underlying assumption of a model, the simulation provides more rapid assessment and enables longer scenarios. The 2 tools are thus complementary.

\section{Experimentation of other roles}

Players were particularly interested in trying other roles that could provide new insights into others parties' management difficulties, the information they were managing, and how they were using it. Thus some months after the game, while most players no longer remembered the exact role they had played or the detailed content of the negotiations, everyone mentioned its capacity to raise their awareness about other actors, their interests, and the influence of their actions on the resources. The traditional contribution of 'off-centre' (decentralised) experience such as RPG or theatre forums (Ferber and Guérin, 2003) also helped them to re-evaluate the indicators and information mobilised by other actors. For example, the legitimacy of indicators used by other actors was enhanced in the eyes of an engineer from the water firm. The experiment also partially called into question the frame of reference of participants who were used to considering that some interest groups had no management strategies but rather acted out of ignorance. However, such calling into question was mostly limited to technical aspects, even if some participants mentioned their increased ability to listen to or to consider other actors' contributions in real meetings and debates, or drew their attention to the relation between decision making, its possible impact on the system, and the potential irreversibility of processes.

\section{Information management}

On the whole, the game has a strong technical emphasis, due on one hand to the complexity of the quality issues, and on the other hand to the involvement of technical scientists in the design stage. A number of companion modelling approaches that deal with water allocation at different scales focus on cooperation between users and rules for sharing water, and are closely related to the institutional economic theoretical framework (Ostrom et al., 1994). Although they present only limited technical aspects of water management, this does not prevent such aspects from emerging during the discussions, as reported in Barnaud et al. (2008). But, right from the start, the objective of our intervention was to deal directly with the problems involved in water quality management, linking the technical and social aspects of management. This meant providing the opportunity to deal with water quality indicators, which stakeholders are less familiar with than water allocation issues.

In spite of the opportunity provided by the game for information sharing (for example through the game-board), interactions enabling the exchange of information were hard to improve. Monitoring the game showed that the players needed more time to adapt, to understand and to appropriate their roles. This often took the whole first round - also called the 'learning round' by the ComMod group - but it could last 2 or 3 rounds depending on the players' ability and the roles they were allocated. The farther the role was from the players' reallife experience, the longer they needed to adapt. Most players mastered the functioning of the game in the second round, but at this stage did not yet fully grasp that their decisions would have direct consequences for the resources and for other players. They generally fully understood the whole set of interrelations between actions and resources only in the third or fourth rounds, when the game is stopped for collective analysis due to lack of time. Thus, the development of cooperative activity and discussions tended to be very progressive. This delay was most serious for players who were not at ease with numbers, because they focused on the quantitative aspects of the games.

One typical interaction resulted from the way the game is designed (which was inspired by the case study). Since the municipality depends on the water management company to create infrastructure for water and sanitation and since the quality of the water in the reservoir depends on municipal urbanisation, bilateral discussions between the water firm and the municipality were among the first relationships developed during the game sessions. However, the players almost failed to recognise this interdependence, which in fact mirrored the limited coordination between water companies and municipalities in real life. Thus, in the game this relationship was developed through peer to peer requests based on individual relationships, rather than through the collective sharing of information or mutual cooperation (example of collective choices concerning areas for urbanisation and the development of infrastructure). But the difficulties in developing effective interactions, even between complementary roles, was particularly interesting to discuss during the debriefing phase. During debriefing special attention was paid to analysing how the information provided was used and mobilised. In particular, this made it possible to debate the value of the information in a discussion, from argumentation support to power resources (Boonstra and Frouws, 2005).

\section{Conclusion}

In IWRM, an institutional catchment committee plays the role of a discussion platform whose aim is to facilitate the integration of non-experts in decision making, provided that actors acknowledge their interdependence and are willing to engage in the discussion process. But the complexity of environmental situations may in fact hinder these interdependencies. Our experiment underlined the fact that a virtual situation in the form of a role-playing game connecting complex biophysical processes and social interactions makes the stakes and issues explicit. The game allows participants to explore the whole cycle of experiential learning as proposed by Kolb (1984): they can investigate the interactions between actors and the environment, observe the consequence of individual actions for the resource and rebuild a representation of this knowledge to assist future actions. It thus provides a frame of analysis of the interaction among stakeholders and a learning platform structured around elements included in the underlying model of the game. The modelling choice results from a balance between representing the whole complexity and simplifying it sufficiently to make it comprehensible and easy to use. Participatory modelling was a key to finding the right balance between the two, and enabled technical and scientific knowledge as well as local knowledge to be integrated in the model. But the results are not limited to learning: the game sessions and debriefings raised awareness of new issues that were initially not shared among actors, such as the role of agriculture or the need to connect water allocation with management of water quality.

If the virtual situation provides interesting insights on how to analyse information exchanges and interactions between management and biophysical processes, the social relationships involved in the negotiation processes do not reflect the complexity of real-life discussions. The roles are limited and social interrelationships between actors are merely functional. The virtual discussion focuses on exchanges concerning 
the 2 resources (information and certain types of economic resources), but does not integrate other resources that can be mobilised in real-life negotiation processes, such as political power or administrative resources (Matus, 1996). Thus if the game is useful in indentifying some of the most important pitfalls of negotiation; it does not aim to provide solutions that can be directly be extrapolated to real situations. Because it deals with a virtual case, the game and the discussions that follow pave the way for a break with conventional ways of acting, and explore new ideas, within a given frame of reference, which in our case was the technical management of water at catchment level. It thus serves as a stepping stone to explore alternatives, even if it should not be seen as a negotiation platform which can provide effective solutions.

\section{Acknowledgements}

This work was conducted with the financial support of the European Commission (INCO project $n^{\circ}$ 2001-10061), of FAPESP 'Fundação de Amparo à Pesquisa do Estado de São Paulo' (Processo n 02/09817-5), and the Agence Nationale de la Recherche, the French National Research Agency (Project ANR-05-PADD-007, ADD-COMMOD). This research would not have been possible without the participation of different people from DAEE, SABESP and the sub-committee of AltoTietê Cabeiceras.

\section{References}

BAKER MJ (2004) Recherches sur l'élaboration de connaissances dans le dialogue: synthèse. Habilitation à Diriger les Recherches, Université de Nancy 2. 246 pp.

BARNAUD C, TREBUIL G, PROMBUROM P and BOUSQUET F (2008) La modélisation d'accompagnement pour une gestion concertée des ressources renouvelables en Thaïlande. Économie rurale 303-304-305 (Janvier-Mai 2008) 39-59.

BAROOS P and LINDEN JVd (1990) The Transformation of Land Supply System in Third World Cities. Averbury, Aldershot.

BAUMGARTNER R, GURDIP A, KARANTH GK and RAMASWAMY V (2002) Researchers in dialogue with local knowledge systems: reflections on mutual learning and empowerment. In: Flury M and Geiser U (eds.) Local Environmental Management in a North-South Perspective: Issues of Participation and Knowledge Management. 225-274.

BECU N, NEEF A and SCHREINEMACHERS PCS (2008) Participatory computer simulation to support collective decision-making: Potential and limits of stakeholder involvement. Land Use Pol. 25 (4) 498-509.

BIANCHINI (Jr.) I (1999) A Decomposição da Vegetação e o Consumo de Oxigênio nos Reservatórios: implicações Ecológicas. In: Henry R (ed.) Ecologia de reservatorios: Estrutura, Função e Aspectos Sociais. 627-650.

BOMMEL P (2009) Définition d'un cadre méthodologique pour la conception de modèles multi-agents adaptée à la gestion des ressources renouvelables. $\mathrm{PhD}$ thesis, Universite Montpellier 2, CIRAD, Montpellier. 309 pp.

BOONSTRA W and FROUWS J (2005) Conflict about water: a case study contest and power in Dutch rural policy. J. Rural Stud. 21 297-312.

BOROWSKI I and HARE M (2007) Exploring the gap between water managers and researchers: difficulties of model-based tools to support practical water management. Water Resourc. Manage. 21 1049-1074.

BOUSQUET F and LE PAGE C (2004) Multi-agent simulations and ecosystem management: a review. Ecol. Model. 176 (3-4) 313-332

BRENNAN E (1994) Mega-city management and innovation strategies: regional views. In: Fuchs RJ, Brennan E, Chamie J, Lo F-C and Uitto JI (eds) Mega-City Growth and the Future. 233-255.
COMMOD C (2006) La modélisation d'accompagnement. In: Amblard $\mathrm{F}$ and Phan D (eds.) Modélisation et Simulation Multi-Agents pour les Sciences de l'Homme et de la Société : une Introduction. Lavoisier, Paris. 217-228.

DOUGLASS M (1992) The political economy of urban poverty and environmental management in Asia: access, empowerment and community based alternatives. Environ. Urbanization 4 (2) 9-32.

DOUROJEANNI A and JOURALEV A (1999) Gestion de Cuencas y Rios Vinculados com Centros Urbanos. CEPAL, Santiago. 176 pp.

ETIENNE M (2006) La modélisation d'accompagnement: un outil de dialogue et de concertation dans les réserves de biosphère. Biodiversité et acteurs, des itinéraires de concertation. UNESCOMAB, Réserves de Biosphère, Note Technique 1 44-52.

EWERT F, VAN KEULEN H, VAN ITTERSUM M, GILLERA K, LEFFELAARA P and ROETTER R (2006) Multi-scale analysis and modelling of natural resource management options. In: Voinov A, Jakeman AJ and Rizzoli AE (ed.) Proc. iEMSs Third Biennial Meeting: 'Summit on Environmental Modelling and Software'. International Environmental Modelling and Software Society, Burlington, USA.

FAROLFI S and ROWNTREE K (2005) Accompanying local stakeholders in negotiation processes related to water allocation through simulation models and role-playing games: an experience from South Africa. EMPOWERS Regional Symposium: End-users ownership and involvement in IWRM, 13-17 November 2005, Cairo, Egypt., 7 pp.

FERBER J and GUÉRIN V (2003) Représentations et simulation : de la modélisation à la mise en situation. Paper presented at:Le statut épistémmologique de la simulation: 10ème journées de Rochebrune: rencontres interdisciplinaires sur les systèmes complexes naturels et artificiels Rochebrune, 26 January - 3 February 2003, Mégève, France.

FOLKE C (2004) Traditional knowledge in social-ecological systems. Ecol. Soc. 9 (3). URL: http://www.ecologyandsociety.org/vol9/iss3/ $\operatorname{art7/}$

GURUNG TR, BOUSQUET F and TRÉBUIL G (2006) Companion modeling, conflict resolution, and institution building: sharing irrigation water in the Lingmuteychu Watershed, Bhutan. Ecol. Soc. 11 (2). URL: http://www.ecologyandsociety.org/vol11/iss2/art36/

HORLITZ T (2007) The role of model interfaces for participation in water management. Water Resourc. Manage. 21 1091-1102.

JACOBI PR and GRANJA SIB (2006) Monitoramento e Análise dos Jogos - Agualoca e Teráguas. Negowat Project PROCAM/USP, São Paulo. 185 pp.

JØRGENSEN SE (2000) Utilização de modelos. In: Jørgensen SE and Vollenweider RA (eds.) Princípios para o Gerenciamento de Lagos. 59-86.

KOLB DA (1984) Experiential Learning: Experiences as Source of Learning and Development. Prentice-Hall, Englewood Cliffs.

LEOPOLD U, FINKE P and ROETTER R (2006) problems and solutions in up- and down-scaling in environmental modelling for the policy scale. In: Voinov A, Jakeman AJ and Rizzoli AE (ed.) Proc. iEMSs Third Biennial Meeting: 'Summit on Environmental Modelling and Software'. International Environmental Modelling and Software Society, Burlington, USA.

MATTINGLY M (1999) Institutional Structures and Processes for Environmental Planning and Management of the Peri-Urban Interface. University College London, London. $9 \mathrm{pp}$.

MATUS C (1996) Estrategias politicas: Chimpanze, Maquiavel e Gandhi FUNDAP, São Paulo.

MAYER I and DE JONG M (2004) Combining GDSS and gaming for decision support. Group Decision and Negotiation 13 223-241.

MCNIE EC (2007) Reconciling the supply of scientific information with user demands: an analysis of the problem and review of the literature. Environ. Sci. Pol. 10 17-38.

OSTROM E, GARDNER R and WALKER J (1994) Rules, Games, and Common-Pool Resources. University of Michigan Press, Ann Arbor.

OXLEY T and LEMON M (2003) From social-enquiry to decision support tools: toward integrative method in the Mediterranean rural environment. J. Arid Environ. 54 595-617. 
OZAWA CP and SUSSKIN L (1985) Mediating science-intensive policy disputes. J. Pol. Anal. Manage. 5 (1) 23-39.

PAHL-WOSTL C (2002) Toward sustainability in the water sectorthe importance of human actors and processes of social learning. Aquat. Sci. 64 394-411.

PAHL-WOSTL C, DOWNING T, KABAT P, MAGNUSZEWSKI P, MEIGH J, SCHLUETER M, SENDZIMIR J and WERNERS $S$ (2005) Transition to adaptive water management. NeWater Working Paper 1. Institute of Environmental Systems Research, University of Osnabrück, Osnabrück.

PORTO M (2003) Recursos hídricos e saneamento na Região Metropolitana de São Paulo: um desafio à tamanho da cidade Banco Mundial, Brasília, DF, Brasil. 84 pp.

PRIME ENGENHARIA (2003) Calibração de sistema relacional de correlação do manejo do território e da qualidade ambiental para o reservatório Billings. Relatorio Parcial RT-2. 36 pp.

SALAS HJ and MARTINO P (1991) A Simplified Phosphorus Trophic State Model for Warm-Water Tropical Lakes Water Res 25 (3) $341-350$.
SENDACZ S, MONTEIRO JUNIOR AJ, MERCANTE CTJ, MENEZES LCB and MORAES JF (2005) Sistemas em cascata: concentrações e cargas de nutrientes no Ssitema Produtor Alto Tietê, São Paulo. In: Nogueira MG, Henry R, Jorcin A (eds.) Ecologia de Reservatórios Impactos Potenciais, Ações de Manejo e Sistemas em Cascata. pp. 417-434.

SHIGAKI F, SHARPLEY A and PROCHNOW LI (2007) Rainfall intensity and phosphorus source effects on phosphorus transport in surface runoff from soil trays. Sci. Total Environ. 373 334-343.

STRASKRABA M (1999) Retention time as a key variable of reservoir limnology. In: Straskraba M and Tundisi JG (eds.) Theoretical Reservoir Ecology and its Applications. pp. 385-410.

SUPLICY MT (2002) Relatório de situação dos Recursos hídricos Sumário Executivo. São Paulo. 67 pp.

VON SPERLING E (1997) The process of biomass formation as the key point in the restoration of tropical eutrophic lakes. Hydrobiologia Mikołajki, Pologne. 351-354.

WIETSKE M. and JEFFREY P (2005) IWRM and adaptive management: Synergy or Conflict? NeWater Report Series No. 7. NeWater, Germany. 43 pp. 
Available on website http://www.wrc.org.za ISSN 0378-4738 (Print) = Water SA Vol. 37 No. 1 January 2011 